\title{
Philosophy as communication theory
}

\author{
Johan Siebers $^{1}$
}

\begin{abstract}
There has been comparatively little attention for the fundamental ontology of communication in recent philosophy. Nevertheless, from classical metaphysical accounts of relationality and communal being to the analysis of intersubjectivity in phenomenology and to concrete existence as understood by process philosophy, the communicative structure of the act of being has been, if not explicitly then implicitly, a perennial component of metaphysical reflection. Communication theory can be conceived in such a way that it takes this ontological dimension into account. The ramifications of connecting being to communication in this way are explored in discussion with the conceptualizations of communication in integrationism and biosemiotics. An interpretation of Gabriel Marcel's existential analysis of "my life" is used to show what philosophy as communication theory (in the strong sense of the notion elaborated here) might look like.
\end{abstract}

Keywords: philosophy of being; communication theory; existentialism; process philosophy; integrationism; biosemiotics; life

It may not be too far-fetched to suggest that integrationism, biosemiotics and philosophy of communication share an idea, perhaps initially not much more than an intuition, about the ubiquity of communication.

For integrationists, all being is contextual relating, or what they call signmaking. The integrationist assumes, out of a kind of ontological prudency, that nothing can really be said about other sign-makers than that we know from first-hand experience, namely ourselves. But allowing for that, not insignificant, qualification, communication is a universal ether within which the sign-maker exists, even more intimately infused by it than a fish by the water that it moves around in and that it breathes. Sign-making goes to very heart of our awareness; we can never catch ourselves or anyone else not doing it.

1 Language and Communication Research Cluster, Middlesex University, London, UK; e-mail: J.Siebers@mdx.ac.uk. 
But also the biosemiotician is struck by the universal nature of the sign. Not troubled by considerations of propriety, this transgressive theoretician sees signmaking as prevalent at least throughout living nature. Biosemiotics goes so far as to suggest that life, sign-making and sign-interpreting are one and the same: the life of signs and the signs of life are co-extensive. Some take a panpsychist line and suggest that the whole universe, understood as everything that can be said to have some kind of integral being, is involved in the life of signs. This opens up a speculative horizon, which for some is too costly in Ockhamite terms to warrant its acceptance (for what does it explain?), while for others it is a wellspring of imaginative generalization that responds to our deeply felt need for a universe of meaning and significance. Some treat this need as the warrant of its own truthfulness. For, the biosemioticians can claim, they have succeeded in finding a way to think about existence as meaningful without subscribing to an overarching meaning or sign-maker. In this happily anarchistic universe, replete with buzzing significance, even the nihilist can have his fun without spoiling anyone else's.

Both traditions thus reap the benefits of, on the one hand, a radical de-transcendentalization, or democratization, of meaning, and, on the other, a radical universalization, or generalization, of communication. Once we accustom ourselves to the intellectual intuition at the base of these ways of thinking, many problems dissolve themselves. For the democratic universalist of communication there is no real substance to the quandaries of modernism and postmodernism, for example, because all meaning is concretized and localized but therefore no less meaningful. Quite the contrary: the idea of an abstract, formal essence of meaning is not something to oppose or rally against, it is something to be unmasked as precisely that: an abstract concept that fails to grasp the concrete reality of communicative significance. Sometimes these theories and their adherents struggle to realize the full significance of their own theories and they fall back into the abstractive way of thinking about meaning themselves. This then leads to the need for correction, by self or others. An example is, in my view, John Deely's account of the ontology of relations, which stays too close to a Thomist framework in which relations are mere entia rationis, deficient in reality and precisely because of that capable of reaching over a manifold of entities (see Deely 2015; Cobley, this issue). The classical account of relationality presupposed a substance-ontological view of reality in which relations have to be grounded, ultimately, in predicates of individual subjects, or qualities of individual substances, rather than that the relations would establish a bond or connection between these entities. But what happens here is a conflation and confusion of a logical account and a metaphysical 
account (and where this happens, it taints semiotics with the air of logicism). ${ }^{2}$ The logic of concepts may indeed invite an account of relations as secondary, deficient modes of being dependent on subject-predicate structures, as these form the necessary skeleton of propositional judgements. An ontological or metaphysical account of the solidarity of the universe has to walk a different path. While also the metaphysician can and should acknowledge that, in Whitehead's words, "relations to do not relate" (Whitehead 2010[1933]: 230), they are "apings of reality" (1978: 229), because they fail to connect, the metaphysical upshot of this verdict is that the realities relations ape are not individual substances with their qualities or a single absolute substance with its modifications, but concrete acts of connectedness. With this realisation, we have the work of the philosophy of communication cut out for us because, with very few exceptions, no one has yet seriously set about the task of developing a philosophy of communication as a fundamental ontology of acts of connection (Pooley 2016).

One exception is the philosophy of A. N. Whitehead. Deleuze and Guattari (2011[1994]: 154) remarked that in Whitehead's philosophy “interaction becomes communication". There is no other ontological account available that so radically and self-consciously dispenses with the abstractions of substance ontology without giving up the sound metaphysical intuition at the base of the notion of substance, or independent existence, as Whitehead's. Whitehead's "occasions" are active moments of communication, of integration of what is given and a creative response to it, and they are ontologically primary. Moreover, Whitehead is fully clear about the status of metaphysical thinking. A metaphysics or ontology is not an abstract account that explains the nature of reality, but a reflective eliciting of self-evidence, a showing or "exhibiting" (to use one of Whitehead's favourite phrases) of concrete existence, itself ultimately inexplicable by abstractions:

The explanatory purpose of philosophy is often misunderstood. Its business is to explain the emergence of the more abstract things from the more concrete things. It is a complete mistake to ask how concrete particular fact can be built up out of universals. The answer is, 'In no way.' The true philosophic question is, How

2 The same tendency, stemming from a lack of metaphysical awareness (concrete is not abstract) can be observed sometimes in integrationist writing, where there is great confusion over the relative status of the sign as repeatable. While integrationist theory hunts down the language myth, the idea of a fixed code as a prerequisite for communication, in all corners of the intellectual universe, I have not found a consistent reflection on the ontological status of the sign as a topic of discourse: the notion of sign is pushed to such a nominalist extreme that any generality seems to be excluded, and yet the theory aims to give a universal account of the sign. It seems that there is a certain blindness here regarding the philosophical status of abstract concepts. 
can concrete fact exhibit entities abstract from itself and yet participated in by its own nature? In other words, philosophy is explanatory of abstractness, and not of concreteness. (Whitehead 1978: 20)

It is not my purpose here to fully discuss Whitehead's ontology as a philosophy of communication. There are serious problems with it, which have to do with the lack of reciprocity that is available to the ontological scheme Whitehead develops and in which each occasion communicates unilaterally only (see Siebers 2018). What is important here, however, is to hold on to the idea that philosophical thinking is not explanatory in the way mentioned by Whitehead, but that its mode of operation is that of showing, exhibiting concrete existence. If we bear this in mind, we will be less prone to mistake philosophical thinking for explanatory, abstract, logical, scientific reasoning and we will be abler to appreciate the genuine philosophical task of explicating intellectual intuition, without which reasoning cannot even begin as it would have nothing to orientate itself by. The philosophy of communication undertakes to do just that kind of explication with respect to communication. But this means that we are not looking at communication as an abstract concept developed to capture certain aspects of reality. Rather, we take the word communication as a tentative explication of concrete existence, as the starting point for the articulation of an intuition. We use the word to elicit an awareness of the unthematic background or context within which our more definite conceptions may acquire meaning and significance. We close-read the word communication as someone might close-read a poem, to become attentive to what the poem is saying. If we refer to the word 'theory' in its original meaning of the activity of viewing, looking, beholding or contemplating ('theoria' is a 'praxis'!), we can say that our philosophy of communication is a communication theory.

My first claim, based on the above, is that such a communication theory is a necessary and basic aspect of thinking about the nature of reality as well as the nature of meaning, semiosis and what in daily life is called communication. A wide field of interpretive contemplation, if not a programme for a philosophy of communication as communication theory, and communication theory as philosophy, is herewith opened up. My second claim is that this form of communication theory, as I have indicated briefly, has something to add to the programme of integrationist thinking as well as that of biosemiotics.

I will not further investigate the second claim here, but instead indicate what the contours of the communication theory envisaged here might look like. In other words, I want to give a concise statement of some of the principles of a strong philosophy of communication. I take the notion of a "strong" account 
or theory here to mean (a) that the notion of communication I want to develop cannot be reduced or deflated to other notions that do not involve the idea of communication, in other words, 'communication' has to be articulated reflectively and on its own terms and part of the philosophy of communication, as we have begun to explore, is to make the case that this is so, and (b) more specifically, that communication is here understood as an ontological notion. This means that the idea of 'communication' provides the means by which to think about being as such. Anything that can be said to 'be' communicates in some way, not abstractly, by the lights of some abstract concept of communication, but concretely speaking. I think that my approach to communication theory can cite Craig's account in support of its manner of proceeding. Craig (1999: 20) views the communication discipline as a dialogical-dialectical field of meta-discourse about communication; of reflections, systematizations, empirical investigations and theorizations of communication as something we are always already familiar with: "[...] all communication theories are relevant to a common practical lifeworld in which communication is already a richly meaningful term". In this sense, all we are doing here is to add a voice to the chorus of communication theories.

There has been a tendency in contemporary analytical philosophy to deny the possibility or desirability of strong accounts of being, as there has indeed been, according to Heidegger, such a tendency to forgetfulness of being throughout the history of metaphysics. It is not my intention here to review the entire philosophy of being, although that is a future task for the kind of communication philosophy I am interested in. ${ }^{3}$ Suffice it here to say that I start from the assumption that we can, in a meaningful way, speak about what it means to be and that, as human beings, we have an implicit and unthematic but undeniable understanding of being. We experience it in our awareness of our own existence and in our ability to experience wonder in the face of the world, a world that is there for us, that is not identical to us, with which we are in communication and in which we communicate with others, in which we live, move and, always tentatively it seems, have our being. We are aware of what was articulated at the beginning of Western philosophy, that the world is both one and many. Philosophy has always sought to understand the nature of the relation between the world as one and the world as many; we can easily chart the history of philosophy as a history of so many attempts at formulating this understanding, from Thales's identification of the principle of all things as water, to Derrida's différance, to name just two. The

3 For a persuasive defence of strong ontologies in direct discussion with analytical philosophy, see White 2014. For a classical statement of the philosophy of being that explicitly addresses communication as an ontological notion, see Blanchette 2003. 
philosophy of being is perhaps nothing more than a particularly subtle way of thinking about unity and plurality. If philosophy is, as one of my teachers used to say, the ever-resurgent struggle against bad philosophy, it may be the case that the mistakes we are prone to when we try to understand, theoretically and practically, the relation between the one and many set philosophy in motion again and again. One of these mistakes would be to take what is abstract for what is concrete, what Whitehead (1978: 7) called "the fallacy of misplaced concreteness". In The Unity of Philosophical Experience, the book in which he made the famous and, in our context, appropriate remark that "philosophy always buries its undertakers", Étienne Gilson (1950: 306) claimed that "the failures of the metaphysicians flow from their unguarded use of a principle of unity present in the human mind":

This new conclusion brings us face to face with the last and truly crucial problem: what is it which the mind is bound to conceive both as belonging to all things and as not belonging to any two things in the same way? Such is the riddle which every man is asked to read on the threshold of metaphysics. It is an easy one, as, after all, was that of the Sphinx; yet many a good man has failed to say the word, and the path to the metaphysical Sphinx is strewn with the corpses of philosophers. The word is - Being. Our mind is so made that it cannot formulate a single proposition without relating it to some being. (Gilson 1950: 312) ${ }^{4}$

Gilson presents the Aristotelian-Thomist philosophy of being as a way to think the one and the many: 'being' is that marvellous gift of language that is not a category or a concept, as Aristotle had already said, but that in which things are both one, because everything is, and many, because everything is what it is and

4 With his remark about the undertakers of philosophy, Gilson was arguing against those who from time to time declare the end of philosophy (in our days eminently represented by the late Stephen Hawking, who declared, at a Google conference in 2011, that "philosophy is dead"). But we can read the remark in a different way if we see that philosophy is a correction of the fallacy of misplaced concreteness, that, in other words, there is no philosophy if there is no bad philosophy to begin with. And, in the process, philosophy kills itself, first as bad, then as good philosophy, and then rises again. We have to thank the undertakers for showing us that the spirit of truth always reaffirms itself, that you can kill a man but you cannot kill an idea. In the case of the physical quest for a Theory of Everything, a great example of the fallacy of misplaced concreteness, Alan White's philosophical theory of everything beautifully performs the duty of the risen corpse, not only so far as the theory of concrete being is concerned, but also our concrete practical existence, which cannot be left out of the unity of philosophy. This may give us hope and occasion for wonder: what is it, in the nature of things, that truth, however waveringly and imperfectly, somehow finds a way but also has to go through its own denial, as if we had to commit a lucky sin to brings us redemption? Are truth and life joined together even closer than biosemiotics dreams of? 
not something else. With the word 'being' and its peculiar behaviour we think and articulate concreteness more concretely and fully than in any other way. Moreover, the metaphysical level of concrete existence and the logical level of abstract judgements also come together in the notion to being. Gilson (quoted in White 2014: 137) again:

[...] the principle [sic] function of the verb is to affirm, and since affirmation remains the same whatever may happen to be affirmed, a single verb should suffice for all affirmations. In point of fact, there is such a verb, and it is "to be". If only spoken usage allowed it, we would never use any other one [...]. Not I live, or I sit, but I am living, I am sitting and likewise in all other cases.

For the tradition of philosophical thinking that Gilson represents, being is the most concrete of all determinations, not the most abstract and empty, as it was, for example, for Kant and Hegel: for Kant, existence adds nothing to the concept but the mere positing of a referent for it. The concept of 100 dollars is no different whether we are talking about real dollars or not. For Hegel, 'being' is the most comprehensive, but therefore also the most empty and indeterminate concept. In both cases, Gilson would argue, we see what happens when we mistake 'being' for a concept. When we say 'to be', or 'being', we have said everything there is to say, albeit so far implicitly only. Being can be explicated infinitely, in word and deed, but the principle of the one and the many is given with the word and with the fact that we can grasp being, however dimly (for the classical philosophy of being several things follow from our grasping of being: that being is necessary, because non-being is inconceivable, that being is true, good, beautiful, one and many). Indeed, intelligibility and our grasp of being are just one and the same thing. Philosophy reminds us of the fact that "there are things to see and that there are things to say" - a phrase used by Merleau-Ponty (1988: 41) to express the wonder with which philosophy begins and within which it dwells.

To say that being is both one and many at the same time, or that beings are both one and many at the same time, and probably in many different ways (I am one to some extent, as an individual, but also many, in that I bring together or integrate into one many different aspects and often also fail to integrate them; but I am also one amid many others) means to say that things, insofar as they are at all, exist within a community of other things. This community is primary and not something that is added to individual things as an afterthought or effect, for example of their relations to others. It has been argued that the real community of beings in being requires a revision of the classical philosophy of being, which makes use of the Aristotelian notion of substance, for which relationality is always ontologically secondary and therefore tainted by abstractness. The case of 
God's Trinitarian nature, a good example of constitutive communication, as the Persons in relation in the Trinity are who they are only in and because of their communication with the other persons and yet each is irreducibly itself, has been used as the model for a generalized ontology of communicative being (Bakker 1968; Clarke 2001). ${ }^{5}$

Because thinking being points us to the fullness of concrete existence, which we always seek to illuminate when we philosophize, and because this fullness of concrete existence is not the logical interdependency of an abstract notion of unity and an abstract notion of plurality, but the concrete, even personal, mutual arising of beings in communication, we have to conclude that the philosophy of being is only the first step of the mind that tries to cure itself of misplaced concreteness and is learning how to walk. The path that opens up ahead leads out of the concerns with what now, looking back once the standpoint of concrete existence has been reached, appears to have been no more than the critique of the logic of being, a self-critique of abstract reasoning that seeks to remind itself of the original intuition from which it sprang. Paradoxically, communication says so much more than being. We have crossed the river and we should now discard the raft, as the Buddhists say. We can leave it there, on the bank, to remind those who will arrive after us that they will have to build their own raft. Communication theory has to start with the reflection on being to obtain an adequate self-understanding and liberate itself from the restrictive idea of theory as abstract concept formation, but once it has reached that self-understanding, it can come into its own and start to speak of communication and use the idea of communication to articulate reality. In the remainder of this article I will do this by considering Gabriel Marcel's (1950: 148-170) treatment of the question "Who am I?".

The Mystery of Being is a two-volume work by Gabriel Marcel, based on his Gifford Lectures in Aberdeen in 1949 and 1950. The text feels quite dated in some aspects. Marcel speaks the language of existentialist thinking in its Christian incarnation. The philosophy expressed in it uses a reflection on being as a way of sensitizing the reader to the fact that we inhabit the world, as a subject amid subjects whom we encounter, and not, or at least not primarily, as an object among objects. Our relations of having are primarily relations of care, based on the way in which we say that we "have a body" or "have a life", and only secondarily, in a derived sense, of the possession of a thing. Our being is an openness in which we can encounter the other, rather than the massive presence of an independent substance. On this basis, the 'mystery', from the title, is of more concern to Marcel

5 Both authors point out, for example, that individuality and community, self and other, are not inversely but directly related: they grow and decline together. 
than the 'being', although the two cannot be detached from each other. The mystery refers to the togetherness in the world. This is a communicative notion for it implies, much like I have said above, both a unity and a plurality, both a sharing and a withholding, a coming together and a remaining separate, as we see in all forms of communication. For Marcel, I always exist in a 'situation', which is not a mere ensemble of things I find myself amid, but a world I encounter with both a degree of freedom and a degree of necessity or thrownness. I am open to the world in the situation of my life. I can also become aware of myself, recognize myself in my situation and experience a call to respond to it creatively, by making something of myself and my life (Marcel 1950: 148-170).

Here, "the question: who am I? remains" (Marcel 1950: 148). Marcel sensitizes us to the epistemological differences between object knowledge and subjective, reflective awareness of myself and my life. I do not exist as an object in the world, about which I could seek the informed counsel of others to obtain a definitive and adequate answer that would settle the question who I am. My friends, my family, my analyst, my union or my employer, the sciences, the economy, nature, politics, etc.: all of these actors and factors in my life represent certain dimensions and certain ways of knowing pertaining to who I am, but none of these, by themselves or in combination, can give me a definitive answer, Marcel argues. To the extent that I seek to outsource the question "Who am I?" exclusively to these presences in my life, I am precisely not living my life but rather trying to get away from it. I am trying to give it away and let someone else take care of it. So I have to consider this question, once it strikes me, for myself, by examining my own life. I can do this by looking at its past, at what it has been, or as something that is still going on: I am living my life now. When I think of the past of my life, I can remember it and I can tell the story of it. I can base myself on my memories, or I can look at traces from the past, such as diaries, pictures or artefacts that were part of my life in one form or another. Marcel argues that I can narrate my life in this way, which means on the one hand "unfold" it here and now as it once was and how it got to be what it is now, and on the other also always select and construe, in other words, "summarize" it. To narrate is both to unfold and to "totalize schematically".

However, also this way of "knowing who I am", like the first one, is not adequate to what it means to be a person and have a life. My words, my works and my acts do not add up to a fully integrated, single unity that would be my life (Marcel 1950: xii). Such a reflective retrieval of my life as a finite whole is not possible at any time. I never know all of my life, just as I do not know fully who I am.

So we have to conclude that my life is always already beyond or behind me, it always escapes me; Marcel says "my life is infinitely beyond the consciousness I have of it", and "always unequal to itself" (Marcel 1950: xii). No form of object 
knowledge is adequate to it. In so far as it is past, also my narrative activity cannot recuperate it. Insofar as it is presently being lived, it escapes my grasp. In which sense, then, can my life be said to be mine at all and which meaning can we give to the question who I am?

Marcel suggests that the mode of being of the person has an irreducible performative dimension. My life is mine as something that is mine to give, to "consecrate" or even "sacrifice" to someone or something (Marcel 1950: xiii). I live my life as truly mine not in my objective knowledge and objective possession of it, but in my ability to devote it to a cause or a purpose (or also more than one), in my ability, in other words, to live it. When I do this, my life acquires meaning and direction and the question "Who am I?" acquires its performative response.

Identity does not primarily lie in the ascription of an essence or selfidentification but in a performative response in the form of commitment and the trust that animates such commitment. If we think in terms of commitment and trust, identity acquires a dimension of openness. Just as my life is beyond my consciousness of it, so is my identity. But my commitment is no less strong because of this; in fact, it is quite the opposite. Just as there is no trade-off between individuality and community, but the two rise and fall together, so there is no trade-off between identity and openness, but a reciprocal reliance of one on the other. Commitment and trust performatively constitute living identity precisely because they give an openness to who we are that is beyond our grasp, that reaches beyond the present into the realms of what is no longer and what is not yet. We might therefore say that commitment and trust can be stronger than death. In this way they give a life integrity or wholeness of a different order than the schematic totalization of the objectified and narrated life. It seems to me that contemporary discussions around identity politics could benefit substantially by reflecting on these intricacies of the communicative constitution of the subject. Now the future can also be given a place in the meaning of "my life" and even the past of it may appear differently to us in the light of such a commitment; a future that was alive but had escaped our notice may finally come out, even in our memories. Our commitment and trust are not blind, of course, but without some form of unconditional giving, it seems impossible to have one's life. Giving one's life does not mean to get rid of it, or of oneself, but it means to respond to a call (this idea is also present in the word 'vocation'). Marcel elaborates the call that we may respond to in terms of intersubjectivity, our openness to others, and, ultimately, in terms of a relation to transcendence. We do not have to follow him there if we do not want to. But we can now see how the existential questions who I am and what it means to live my life are here elaborated in a communicative context. To speak of a 'call' implies no mythology or metaphor, the transposition of a concept 
that refers to something in a literal sense to a figurative domain, simply because there is no "literal" way of saying what we say here without the use of a word like 'call. Marcel's articulation of the relation between me and my life is therefore not an example of conceptual metaphor (Lakoff, Johnson 2003). If anything, it is the reverse. We draw upon our implicit understanding of what is involved in calling as an intersubjective, communicative practice (such as recognition, freedom to respond or not, etc.) when we use this word in its daily meaning. But that implicit understanding is there, it is operative, and it needs philosophy as communication theory to make it explicit.

I have used this example merely as an illustration of a philosophical use of the idea of communication. There are many more dimensions, phenomena and practices that can be explored in this way and that have already been addressed by others. The dialogic philosophy of Martin Buber is an example of a philosophy of communication that operates at the same level as what I have tried to bring forward in this short text. Buber (2018: 12) writes, in I and Thou, that the primary word-pairs "I-it" and "I-Thou" "bring about existence" when they are spoken "when a primary word is spoken the speaker enters the word and takes his stand in it". This is not metaphoric or merely belletrist language. What I hope I have begun to show is that the philosophical valorization of the idea of communication requires that we take our departure from a reflection on being. Only that brings out the potential of philosophy as communication theory, and only that makes visible the urgency and the newness of it. One final illustrative conclusion that I can point to is that the theory of speech acts is only in its infancy. Practices such as the call and the response, but also practices such as testifying, witnessing, praising, blaming, joking, telling, lying, conversing, how we speak when we are in love or when we hate, etc., all have their implicit, often unconscious, depths which the philosophy of communication can try to fathom, as far as possible. They are all speech acts, when we take that term in a wider sense than how it is mostly used, namely as referring to the way we exist in speech, as the "parlêtre" Lacan (Lacan, Aubert 1986: 27) spoke of.

I started this paper with a reference to integrationism and to biosemiotics. I was led to that by the workshop at Middlesex University London at which this paper originated and where I presented the first part, about the explanatory purpose of philosophy. The purpose of the workshop was to bring together representatives of the three paradigms or approaches in the thinking about communication and see what they might learn from one another. Both of the other paradigms share with the philosophy of communication, as I have sketched it here, the idea that we have to understand communication on its own terms. It seems to me that the case for this claim still needs to be made, despite the long history that exists by now of 
thinkers who have held this view. Fortunately, each of the three approaches does just that, each in their own way. As a literal example of triangulation, I submit that the case for that claim is now stronger than ever and not only that, we also have a better insight into what it means to understand communication on its own terms.

\section{References}

Bakker, Anton 1968. Relatie als kommunikatie. Kritische beschouwing van de thomistische relatieleer. Bijdragen 29: 259-287. https://doi.org/10.1080/00062278.1968.10596854

Blanchette, Oliva 2003. Philosophy of Being: A Reconstructive Essay in Metaphysics. Washington: Catholic University of America Press.

Buber, Martin 2018[1923]. I and Thou. (Smith, Ronald Gregor, trans.) London: Bloomsbury.

Clarke, W. Norris 2001. The One and the Many: A Contemporary Thomistic Metaphysics. Notre Dame: University of Notre Dame Press.

Craig, Robert 1999. Communication theory as a field. Communication Theory 9(2): 119-161. https://doi.org/10.1111/j.1468-2885.1999.tb00355.x

Deely, John 2015. Objective reality and the physical world: Relation as key to understanding semiosis. Green Letters 19(3): 267-279. https://doi.org/10.1080/14688417.2015.1063239

Deleuze, Gilles; Guattari, Félix 2011[1991]. What Is Philosophy? London: Verso.

Gilson, Etienne 1950. The Unity of Philosophical Experience. New York: Charles Scribner's Sons. Lacan, Jacques; Aubert, Jacques 1986. Joyce Avec Lacan. Paris: Navarin.

Lakoff, George; Johnson, Mark 2003. Metaphors We Live By. Chicago: University of Chicago Press.

Marcel, Gabriel 1950. The Mystery of Being 1: Reflection and Mystery. New York: Henry Regnery. Merleau-Ponty, Maurice 1988[1953, 1968]. In Praise of Philosophy and Other Essays. (Wild, John; O’Neill, James Edie John, trans.) Evanston: Northwestern University Press.

Pooley, Jefferson D. 2016. Communication theory and the disciplines. In: Jensen, Klaus Bruhn; Craig, Robert T. (eds.), The International Encyclopedia of Communication Theory and Philosophy. Vol. 1. Chichester: John Wiley and Sons, 286-301. https://doi. org/10.1002/9781118766804.wbiect261

Siebers, Johan 2018. The theory of perfective drift. In: Smith, Andrew R.; Catt, Isaac E.; Klyukanov, Igor E. (eds.), Communicology for the Human Sciences: Lanigan and the Philosophy of Communication. New York: Peter Lang, 369-389.

White, Alan 2014. Toward a Philosophical Theory of Everything: Contributions to the StructuralSystematic Philosophy. London: Bloomsbury.

Whitehead, Alfred North 1978[1929]. Process and Reality: An Essay in Cosmology: Gifford Lectures Delivered in the University of Edinburgh during the Session 1927-28. (Griffin, David Ray; Sherburne, Donald W., corr. ed.) New York: The Free Press.

Whitehead, Alfred North 2010[1933]. Adventures of Ideas. New York: The Free Press. 


\section{Философия как теория коммуникации}

Фундаментальной онтологии коммуникации в современной философии уделяется сравнительно мало внимания. Тем не менее, от классических метафизических рассуждений о реляционности и общности до анализа интерсубъективности в феноменологии и конкретного бытия в понимании философии процесса, коммуникативная структура акта бытия если и не эксплицитно, то имплицитно, являлась многолетней составляющей метафизической рефлексии. Теория коммуникации может быть задумана таким образом, что она будет учитывать это онтологическое измерение. Последствия такого рода связи бытия с коммуникацией исследуются в диалоге с концептуализациями коммуникации в интеграционизме и биосемиотике. Чтобы показать, как может выглядеть философия в качестве теория коммуникации (в смысле разработанного здесь понятия), используется интерпретация экзистенциального анализа «моей жизни» Габриэля Марселя.

\section{Filosoofia kui kommunikatsiooniteooria}

Uuemas filosoofias on võrdlemisi vähe tähelepanu pööratud kommunikatsiooni fundamentaalsele ontoloogiale. Sellele vaatamata on olemisakti kommunikatiivne struktuur, kui mitte eksplitsiitselt, siis implitsiitselt, olnud üks metafüüsilise refleksiooni püsivaid koostisosi, alates relatsioonilisuse ja ühisolemise klassikalistest metafüüsilistest seletustest kuni intersubjektiivsuse analüüsini fenomenoloogias ning konkreetse eksistentsini, nagu seda mõistetakse protsessifilosoofias. Kommunikatsiooniteooriat võib kujutleda nii, et arvestatakse seda ontoloogilist mõõdet. Olemise sel moel kommunikatsiooniga ühendamise harusid vaadeldakse dialoogis kommunikatsiooni kontseptualiseeringutega integratsionismis ja biosemiootikas. Kasutatakse Gabriel Marceli „minu elu“ eksistentsiaalse analüüsi tõlgendust, näitamaks, kuidas võiks välja näha filosoofia kui kommunikatsiooniteooria (selle mõiste siinkohal lahti kirjutatud tugevas tähenduses). 